\title{
Effect of Glyphosate Application on Sudden Death Syndrome of Glyphosate-Resistant Soybean Under Field Conditions
}

Yuba R. Kandel, Department of Plant Pathology and Microbiology, Iowa State University, Ames, IA 50011; Carl A. Bradley, Department of Crop Sciences, University of Illinois, Urbana, IL 61801; Kiersten A. Wise, Department of Botany and Plant Pathology, Purdue University, West Lafayette, IN 47907-2054; Martin I. Chilvers, Department of Plant, Soil and Microbial Sciences, Michigan State University, East Lansing, MI 48824; Albert U. Tenuta, Ontario Ministry of Agriculture and Food, Ridgetown, ON N0P2C0, Canada; Vince M. Davis, Department of Agronomy, University of Wisconsin-Madison, WI 53706; Paul D. Esker, School of Agronomy, University of Costa Rica, San Jose, CR; Damon L. Smith, Department of Plant Pathology, University of WisconsinMadison; and Mark A. Licht, Department of Agronomy, and Daren S. Mueller, Department of Plant Pathology and Microbiology, Iowa State University, Ames

\begin{abstract}
Kandel, Y. R., Bradley, C. A., Wise, K. A., Chilvers, M. I., Tenuta, A. U., Davis, V. M., Esker, P. D., Smith, D. L., Licht, M. A., and Mueller, D. S. 2015. Effect of glyphosate application on sudden death syndrome of glyphosate-resistant soybean under field conditions. Plant Dis. 99:347-354.

Sudden death syndrome (SDS), caused by Fusarium virguliforme, is an important yield limiting disease of soybean. Glyphosate is used to control weeds in soybean; however, its effect on SDS is not clearly understood. The objective of this study was to examine the impact of glyphosate on SDS, yield, and plant nutrition under field conditions. Fourteen field experiments were conducted in Iowa, Illinois, Indiana, Michigan, Wisconsin, and Ontario, Canada during 2011 to 2013. The experiment consisted of six treatment combinations of glyphosate and herbicides not containing glyphosate. Disease index was significantly different across the location-years, ranging from 0 to 65 . The highest

disease was noted in locations with irrigation, indicating that high soil moisture favors development of SDS. There were no effects of herbicide treatments or interactions on disease. The foliar disease index among the treatments over all years ranged from 9 to 13. Glyphosate-treatments also tended to yield more than treatments of herbicides not containing glyphosate. There were no interactions between glyphosate-treatments and total manganese in plant tissue. The interaction of glyphosate with other nutrients in plant tissue was inconclusive. This 14 location-year study demonstrated that glyphosate application did not increase SDS severity or adversely affect soybean yield under field conditions.
\end{abstract}

Sudden death syndrome (SDS) of soybean (Glycine max (L.) Merr.) is caused by four different soilborne Fusarium spp. (35,47). In North America, Fusarium virguliforme O'Donnell \& T. Aoki (synonym: F. solani (Mart.) Sacc. f. sp. glycines) is the only species detected that causes SDS $(3,35)$. The disease was first observed in Arkansas in 1971 (47); since then, it has extensively spread, covering all major soybean-growing areas of the United States and parts of Canada $(2,12,35)$. SDS has become one of the major factors limiting yield, especially in environments with high yield potential, where yield loss may range from nearly $0 \%$ to almost $100 \%$, depending upon stage of the crop at the time when disease symptom appears and disease severity $(35,50,52)$. The fungus survives in soil and initially infects soybean roots, causing root and crown rot, especially under cool, moist spring conditions (25). The fungus produces mycotoxins that move from roots to plant shoots, causing foliar symptoms $(8,35)$. Foliar symptoms of SDS are generally noticed during reproductive stages, between the R3 and R6 growth stages $(21,35,46)$, although it has been reported in earlier growth stages in some genotypes (49). Foliar symptoms begin as interveinal chlorosis and, if weather remains conducive, they progress to interveinal necrosis and premature defoliation, leaving petioles intact to the main stem.

Management of the disease should first include planting soybean cultivars with host plant resistance, although no cultivars are completely resistant to $\operatorname{SDS}(8,16,28,29,40,41)$. Due to the lack of complete resistance in soybean against $F$. virguliforme, integrating other agronomic management options such as cultural practices has

Corresponding author: D. Mueller, E-mail: dsmuelle@ iastate.edu

Accepted for publication 15 August 2014.

http://dx.doi.org/10.1094/PDIS-06-14-0577-RE

(C) 2015 The American Phytopathological Society become critically important in mitigating losses caused by the disease. Some cultural practices associated with lower levels of SDS include managing soybean cyst nematode, increased drainage through use of drainage tiles, strategic tillage, and adjusting planting date to avoid cool and wet soil conditions that are conducive for plant infection by $F$. virguliforme $(35,51,57)$. Another cultural management strategy may include altering the amount or type of herbicide used for weed control because some herbicides have been shown to influence disease incidence $(1,54,55)$. In recent years, the widely used herbicide glyphosate (N-(phosphonomethyl)glycine) has been purportedly associated with higher levels of disease in soybean $(7,27,33,54,55)$.

Glyphosate-resistant (GR) soybean cultivars are widely planted primarily because they facilitate in-season glyphosate application for weed management without causing severe injury to soybean. The introduction of GR soybean cultivars in the United States and Canada has led to substantial changes in farming practices. According to the United States Department of Agriculture, GR soybean now accounts for more than $90 \%$ of total soybean cultivation in the United States (58). Along with adoption of GR soybean lines, application of glyphosate has also increased dramatically because it has many desirable properties (19). The herbicide has low toxicity to mammals and is environmentally safe and nonselective. More importantly, it can be applied "as needed" in the field, reducing application of preemergence (PRE) or post-emergence (POST) applications of other herbicides (19). Glyphosate has been used since 1974 to control weeds in various crops and, except for evolution of GR weeds, few harmful secondary effects have been linked to its use (19). However, recent reports have indicated that glyphosate may have adverse effects and increase severity of diseases in soybean $(7,27,33,34,42,54,55)$. These reports have drawn considerable attention from plant pathologists, farmers, and the general public. A recent review published by Johal and Huber (33) listed 34 diseases that increased due to glyphosate use in many crops, including soybean. Sanogo et al. $(54,55)$ reported that herbi- 
cide application, including glyphosate, increased severity of SDS and $F$. virguliforme colonization in the roots. Although these reports revealed that glyphosate use was correlated with increased disease development, previous investigations have also indicated that glyphosate can reduce the severity of certain diseases $(1,22,23,39)$. Previous studies on wheat showed that glyphosate reduced stripe rust (caused by Puccinia striiformis f. sp. tritici), leaf rust (caused by $P$. triticina Erikss.) $(1,22)$, and common root rot (caused by Cochliobolus sativus (S. Ito \& Kurib.) Drechsler ex Dastur; anamorph Bipolaris sorokiniana (Sacc.) Shoemaker) on wheat (23). Research also has demonstrated that glyphosate can reduce soybean rust (caused by Phakopsora pachyrhizi Syd.) when applied both before and soon after infection (22).

Glyphosate use also can cause a "yellow flash" symptom 4 to 20 days following glyphosate applications under certain environmental conditions $(19,53)$. Yellow flash associated with glyphosate applications has symptomology of leaf chlorosis that can resemble iron chlorosis or manganese deficiency. It is now known that yellow flash is due to glyphosate metabolism to aminomethylphosphonate and rarely results in significantly reduced plant growth or yield loss $(19,20,30,53)$.

Research results both support and refute claims of nutrient deficiencies associated with glyphosate applications, as well as nutrient accumulation in soybean leaves and seed $(6,9,18,31,32,37,45)$. Dodds et al. $(17,18)$ identified yellow flash and associated manganese deficiency in soil with low manganese soil test results. Graham et al. (26) found that susceptibility to manganese deficiency is influenced by soybean genetic variation. Manganese fertilizer application is generally not recommended unless deficiencies are observed $(10,31,37)$.

Glyphosate application programs in commercial soybean fields depend on several factors such as field history, crop density, weed type and density, weed height, planting date, environmental conditions, and so on $(13,14)$. Consequently, glyphosate use may vary from field to field. In order to determine how glyphosate use affects SDS severity and plant nutrition, it is necessary to consider different rates, number of applications in a season, and application timing under field conditions. Evidence to prove or disprove the link of glyphosate usage with crop disease is lacking, particularly with SDS. Previous reports examining the effect of herbicides on
SDS were based on greenhouse studies or limited field uses, and did not include multiple rates and multiple applications in a season $(54,55)$. This multilocation study reports the effect of glyphosate application (including different doses and timings) on severity of SDS, grain yield, and plant nutrition. The goal of this study is to help farmers determine whether to change or adjust their weed management programs to help manage SDS.

\section{Materials and Methods}

The study was conducted in five states in the United States and the province of Ontario in Canada, representing different geographical regions, weather, and soil types. In total, 14 field experiments were carried out from 2011 to 2013 . The number and location of experiment sites were different each year (Table 1). Field experiments were laid out in a randomized complete block design with four replicates.

Soybean was planted as soon as conditions were acceptable for planting at each location, and this ranged from the last week of April through the first week of June. The crop preceding these trials was corn at all but one location, and the seedbed was prepared with tillage at most locations whereas some were directseeded without preplant tillage (Table 1).

All cultivars used in this study were glyphosate resistant and seed received no seed treatments. Cultivars and their SDS ratings (according to respective companies) are listed in Table 1. The experimental unit was one research plot. Plot size for each treatment varied across the locations, ranging from $9.1 \mathrm{~m}^{2}$ (plots in Ontario) to $28.3 \mathrm{~m}^{2}$ (plots in Indiana) (data not shown). Each plot had four rows spaced 38.1 to $76.2 \mathrm{~cm}$ apart.

Experiments were established in fields with a history of SDS. Several of the experiments were also supplemented with inoculum of $F$. virguliforme to induce disease, while a few locations relied solely on natural inoculum (Table 1). Where used, supplemental inoculum was introduced in each plot by adding $F$. virguliformeinfested sorghum or oat grains with soybean seed at planting. Inoculum was prepared using a single-spore-generated culture of the fungus following the protocol described by Li et al. (36). Fungal isolates and rate of inoculum used in the field experiments are given in Table 1. Most field experiments were conducted with only natural rainfall, except Illinois and Michigan, which also received

Table 1. Experiment information, cultivars, and field conditions for the 14 experiments carried out in five states of the United States and the province of Ontario, Canada to study the effect of glyphosate on sudden death of syndrome (SDS) of glyphosate-resistant soybean during 2011 to 2013 soybean-growing seasons ${ }^{t}$

\begin{tabular}{|c|c|c|c|c|c|c|c|c|c|c|c|c|}
\hline Year & Location ${ }^{u}$ & County & $\begin{array}{c}\text { Planting } \\
\text { date }\end{array}$ & $\begin{array}{c}\text { Cultivar } \\
\text { (SDS rating) }^{\mathrm{v}}\end{array}$ & $\begin{array}{c}\text { SDS } \\
\text { rating date }\end{array}$ & $\begin{array}{c}\text { SDS } \\
\text { rating } \\
\text { GSw }^{w}\end{array}$ & $\begin{array}{c}\text { Leaf } \\
\text { sampling } \\
\text { date }^{\mathrm{x}}\end{array}$ & Harvest date & Inoc $^{y}$ & Tillage & $\begin{array}{l}\text { Previous } \\
\text { crop }\end{array}$ & Irrig $^{z}$ \\
\hline 2011 & Ames, IA & Story & 4 May & AG 2531 (4) & 29 August & R5, R6 & 13 July & 3 October & No & Yes & Corn & No \\
\hline 2012 & Ames, IA & Story & 25 April & AG 2631 (3) & 28 August & R5 & 24 July & 28 September & Yes & Yes & Corn & No \\
\hline 2013 & Ames, IA & Story & 3 June & AG 2431 (6) & 12 September & R6-R7 & 9 August & 30 September & Yes & Yes & Corn & No \\
\hline 2011 & Urbana, IL & Champaign & 2 June & FS Hisoy $28 \mathrm{~A} 02$ & 6 September & R5, R6 & 1 July & 6 October & Yes & Yes & Corn & Yes \\
\hline 2012 & Urbana, IL & Champaign & 24 April & Kruger 2901 & 21 August & R5, R6 & - & 10 October & Yes & Yes & Soybean & Yes \\
\hline 2013 & Urbana, IL & Champaign & 21 May & NK 36-B6 & 30 August & R5, R6 & 14 June & 10 October & Yes & Yes & Corn & Yes \\
\hline 2011 & Lafayette, IN & Tippecanoe & 18 May & P93M42 (6) & 1 September & R6 & 18 June & 7 October & Yes & No & Corn & No \\
\hline 2013 & Lafayette, IN & Tippecanoe & 13 May & DSR 3216/R2Y (1.8) & 13 September & R6-R7 & 16 June & 26 September & Yes & Yes & Corn & No \\
\hline 2012 & Decatur, MI & Van Buren & 6 May & AG 2107 (4) & 21 August & R6 & - & 2 October & No & Yes & Corn & Yes \\
\hline 2013 & Decatur, MI & Van Buren & 1 May & AG 3030 (5) & 16 August & R6 & 13 June & 3 October & No & Yes & Corn & Yes \\
\hline 2012 & Rodney, ON & Elgin & 24 May & P31-11RY (5) & 9 August & $\mathrm{R} 4$ & - & 4 October & No & Yes & Corn & No \\
\hline 2013 & Rodney, ON & Elgin & 8 June & P31-11RY (5) & 8 August & $\mathrm{R} 4$ & 19 July & 23 October & No & Yes & Corn & No \\
\hline 2011 & Arlington, WI & Columbia & 6 May & NK S21-N6 (5) & NA & NA & 20 July & 5 October & Yes & No & NA & No \\
\hline 2013 & Arlington, WI & Columbia & 8 May & AG2431 RR2 (4) & 5 September & R6-R7 & - & 2 October & Yes & Yes & Corn & No \\
\hline
\end{tabular}

${ }^{\mathrm{t}} \mathrm{NA}=$ not available and - indicates that leaf samples were not taken.

"City and state or province: IA = Iowa, IL = Illinois, IN = Indiana, MI = Michigan, ON = Ontario, Canada, and WI = Wisconsin.

${ }^{v}$ Pioneer (P) cultivars on a 1-to-9 scale, with $1=$ susceptible; Asgrow (AG) cultivars on a 1-to-9 scale, with 1 = best; Dairyland seed (DSR) cultivars on a 1to-5 scale, with 1 = best; Northrup King (NK) cultivars on a 1-to-9 scale, with $1=$ best.

${ }^{\mathrm{w}} \mathrm{GS}=$ growth stage.

${ }^{x}$ Date of leaf sampling for nutrient analysis.

y In Iowa, inoculated with the Fusarium virguliforme isolate NE 305 at $8.3 \mathrm{~g} / \mathrm{m}$ of linear row; in Illinois, inoculated with the isolate Mont-1 at infested ground sorghum at $4.1 \mathrm{~cm}^{3} / \mathrm{m}$ of linear row; in Indiana, inoculated with a mixture of three isolates collected in Indian (NRRL 22823, 00-11-183, and INS12-10-3-1) at $4.2 \mathrm{~g} / \mathrm{m}$ of linear row; and in Wisconsin, inoculated with a mix of three $F$. virguliforme isolates (unknown designations) at $3.3 \mathrm{~g} / \mathrm{m}$ of linear row.

${ }^{\mathrm{z}}$ Irrigation set up in Illinois was drip irrigation set up within 20 days after planting, and ran for approximately 75 consecutive days with approximately 1.3 $\mathrm{cm}$ of water delivered each day; irrigation in Michigan was done by using a center-pivot irrigation unit established in field. Irrigation was started after planting and run once a week depending on weather. Approximately $1.3 \mathrm{~cm}$ of water was delivered in each time. 
supplemental water through irrigation (Table 1). Monthly rainfall amounts for each location-year were obtained either from the weather stations installed in the field or from public weather service websites (http://www.nws.noaa.gov/climate/ or http://mesonet. agron.iastate.edu/request/coop/obs-fe.phtml). Soil temperature at planting was recorded at the depth of 5 to $10 \mathrm{~cm}$ in the same or an adjacent field (Table 2).

Six herbicide treatments were compared in this study. Treatments included different combinations of glyphosate use rates, application timings, and number of applications along with nonglyphosate herbicides as controls (Table 3). Glyphosate is an EPSP synthase inhibitor (group $\mathrm{G}$ according to the Herbicide Resistance Action Committee (HRAC; www.hracglobal.com/Education/Clas sificationofHerbicideSiteofAction.aspx). One glyphosate-containing herbicide was used in the experiments: Roundup PowerMAX (Monsanto Company, St. Louis, MO). Flexstar (Syngenta Crop Protection, Inc., Greensboro, NC) contains fomesafen, which is a protoprophyrinogen oxidase (PPO) inhibitor (group E). Four other nonglyphosate herbicides were also used, including an acetyl-CoA carboxylase (ACCase) inhibitor (group A), Select Max (clethodim; Valent U.S.A. Corporation, Walnut Creek, CA); a PPO inhibitor, Valor XLT (flumioxazin; Valent U.S.A. Corporation); and two acetolactate synthase (ALS) inhibitors (group B), Pursuit (imazethapyr; BASF Corporation, Florham Park, NJ), and FirstRate (cloransulam-methyl; Dow AgroSciences LLC, Indianapolis, IN). PPO inhibitors and ALS inhibitors have been associated with increased root rot severity on soybean (27). Herbicides were applied using different sprayers and nozzles. In Iowa, they were applied in 2011 and 2012 with a $\mathrm{CO}_{2}$-pressurized backpack sprayer at 241 $\mathrm{kPa}$. The sprayer was equipped with four flat fan nozzles spaced 51 $\mathrm{cm}$ apart and calibrated to apply 187 liters/ha. In 2013, they were sprayed with a self-propelled small research plot sprayer consisting of seven flat fan nozzles spaced $51 \mathrm{~cm}$ apart and sprayed at the pressure of $241 \mathrm{kPa}$. In Illinois, they were applied using a hand boom sprayer with AI 11002 standard flat spray nozzles (TeeJet Spraying Systems Co., Wheaton, IL), spaced $48 \mathrm{~cm}$ apart at spray pressure $276 \mathrm{kPa}$. In Indiana, they were applied with a $\mathrm{CO}_{2}$-pressurized backpack sprayer and a hand-held boom fitted with four TJ-8002VS nozzles spaced $48 \mathrm{~cm}$ apart, which delivered 140 liters/ha at $207 \mathrm{kPa}$. In Michigan, they were applied in 2012 with a hand-held spray boom pressurized with $\mathrm{CO}_{2}$ at $276 \mathrm{kPa}$. The spray boom consisted of four nozzles (Teejet AIXR-11002) spaced 51 $\mathrm{cm}$ apart and was calibrated to apply 140 liters/ha. In 2013, the boom consisted of six nozzles (Teejet 11001VS) spaced $51 \mathrm{~cm}$ apart and was calibrated to apply 140 liters/ha. In Ontario, the treatments were applied with a $\mathrm{CO}_{2}$-pressurized backpack sprayer at $241 \mathrm{kPa}$ with AI 11002 flat fan jet nozzles. In Wisconsin, herbicide treatments were applied with a $\mathrm{CO}_{2}$-pressurized hand boom with eight XR11002 nozzles (TeeJet Spraying Systems Co.) spaced $38 \mathrm{~cm}$ apart, calibrated to deliver 140 liters/ha. When weed pressure was high, the grass herbicide Authority Assist at $0.11 \mathrm{~kg}$ a.i./ha was applied in the entire field (all plots) to reduce the pressure of grassy weeds in Illinois. In Indiana, Select was applied at $0.11 \mathrm{~kg}$ a.i./ha in the entire field in 2013 to control the grass weeds. In 2011, no herbicide was applied but weeds were manually removed. In Iowa, Michigan, Ontario, and Wisconsin, infestations of grass weeds did not require broadcast grass herbicides; however, supplemental hand weeding was done as needed.

Foliar severity was recorded using a previously reported disease rating scale $(24,44)$ during reproductive stages $\mathrm{R} 5$ through $\mathrm{R} 7(21)$, depending on the onset of SDS foliar symptoms. Disease incidence was estimated as the percentage of symptomatic plants in the plot

Table 2. Soil temperature at planting and monthly precipitation recorded during the soybean growing seasons at the experiment-sites in the five states of the United States and Canada from 2011 to $2013^{\mathrm{w}}$

\begin{tabular}{|c|c|c|c|c|c|c|c|c|c|c|c|c|c|c|c|c|c|}
\hline \multirow[b]{2}{*}{ Year } & \multirow[b]{2}{*}{ State $^{y}$} & \multirow[b]{2}{*}{ City } & \multirow[b]{2}{*}{ County } & \multirow[b]{2}{*}{$\mathbf{T m}^{\mathbf{z}}$} & \multicolumn{7}{|c|}{ Monthly precipitation $(\mathbf{c m})^{x}$} & \multicolumn{6}{|c|}{ 30-year average monthly precipitation $(\mathrm{cm})$} \\
\hline & & & & & May & June & July & August & Sept & Oct & Total & May & June & July & August & Sept & Oct \\
\hline 2011 & IA & Ames & Story & 9.4 & 11.9 & 10.9 & 0.3 & 8.6 & 6.9 & 0.0 & 38.9 & 12.2 & 12.7 & 12.2 & 12.2 & 8.1 & 6.6 \\
\hline 2012 & IA & Ames & Story & 14.4 & 6.4 & 8.4 & 5.8 & 3.3 & 5.3 & 6.1 & 34.8 & 12.4 & 12.7 & 11.9 & 11.9 & 8.1 & 6.6 \\
\hline 2013 & IA & Ames & Story & 17.8 & 22.9 & 9.4 & 2.3 & 3.8 & 3.6 & 7.4 & 48.8 & 13.0 & 12.7 & 11.7 & 11.7 & 8.1 & 6.6 \\
\hline 2011 & IL & Urbana & Champaign & 21.8 & 12.2 & 10.7 & 4.0 & 4.5 & 7.1 & 6.7 & 45.2 & 12.4 & 11.0 & 11.9 & 10.0 & 8.0 & 8.3 \\
\hline 2012 & IL & Urbana & Champaign & 14.4 & 9.0 & 4.6 & 1.4 & 14.2 & 14.2 & 13.7 & 57.1 & 12.4 & 11.0 & 11.9 & 10.0 & 8.0 & 8.3 \\
\hline 2013 & IL & Urbana & Champaign & 24.5 & 11.8 & 13.5 & 8.8 & 1.2 & 1.3 & 10.6 & 47.2 & 12.4 & 11.0 & 11.9 & 10.0 & 8.0 & 8.3 \\
\hline 2011 & IN & Lafayette & Tippecanoe & 13.9 & 10.2 & 9.6 & 4.7 & 2.6 & 8.4 & 0.0 & 35.5 & 11.3 & 11.6 & 10.4 & 10.0 & 7.1 & 6.9 \\
\hline 2013 & IN & Lafayette & Tippecanoe & 11.7 & 2.6 & 5.7 & 5.0 & 4.1 & 1.4 & NA & 18.8 & 11.3 & 11.6 & 10.4 & 10.0 & 7.1 & 6.9 \\
\hline 2012 & MI & Decatur & Van Buren & NA & NA & NA & 11.6 & 10.5 & 6.7 & NA & NA & NA & NA & NA & NA & NA & NA \\
\hline 2013 & MI & Decatur & Van Buren & NA & NA & 10.3 & 8.7 & 10.0 & 2.6 & NA & NA & NA & NA & NA & NA & NA & NA \\
\hline 2012 & ON & Rodney & Elgin & NA & 6.7 & 8.2 & 16.9 & 6.7 & 8.2 & 12.0 & 58.7 & 8.3 & 7.3 & 7.9 & 8.5 & 8.8 & 6.8 \\
\hline 2013 & ON & Rodney & Elgin & NA & 8.2 & 10.9 & 6.2 & 7.7 & 6.9 & 12.2 & 52.1 & 8.3 & 7.3 & 7.8 & 8.4 & 8.8 & 7.0 \\
\hline 2011 & WI & Arlington & Columbia & 13.3 & 6.2 & 9.0 & 5.4 & 3.8 & 10.0 & 4.0 & 38.4 & 10.5 & 12.4 & 10.8 & 10.9 & 9.0 & 6.6 \\
\hline 2013 & WI & Arlington & Columbia & 12.8 & 15.8 & 18.9 & 6.9 & 4.2 & 7.3 & 5.0 & 58.1 & 10.5 & 12.4 & 10.8 & 10.9 & 9.0 & 6.6 \\
\hline
\end{tabular}

${ }^{\mathrm{w}} \mathrm{NA}=$ Not available.

$x$ Precipitation including irrigation.

${ }^{y}$ IA = Iowa, IL = Illinois, IN = Indiana, $\mathrm{MI}=$ Michigan, and ON = Ontario in Canada, and WI = Wisconsin .

${ }^{\mathrm{z}}$ Soil temperature $\left({ }^{\circ} \mathrm{C}\right)$ at planting was recorded at a depth of $10 \mathrm{~cm}$ in Iowa, Illinois, and Indiana and $5 \mathrm{~cm}$ in Wisconsin.

Table 3. Treatment list for field experiments examining effect of herbicide treatments on sudden death syndrome of glyphosate-resistant soybean in Iowa, Illinois, Indiana, Michigan, Wisconsin, and Ontario Canada during the years 2011, 2012, and 2013

\begin{tabular}{llc}
\hline Herbicide $^{\mathbf{x}}$ & Application timing $^{\mathbf{y}}$ & Rate (active ingredient or active equivalent in kg/ha) $^{\mathbf{z}}$ \\
\hline Roundup PowerMAX & V3/V4 & 3.25 \\
Roundup PowerMAX & Planting, then V3/V4 & 1.63 then 0.79 \\
Roundup PowerMAX & V3/V4, then 3 weeks later & 1.63 then 0.79 \\
Preemergence, then Roundup PowerMAX & Preemergence, then V3/V4 & By state, then 1.73 \\
Preemergence, then Flexstar + Select MAX + COC & Preemergence, then V3/V4 & By state, then $0.34+0.63$ \\
Preemergence, then Pursuit + AMS & Preemergence, then V3/V4 & By state, then 0.07 \\
\hline
\end{tabular}

${ }^{\mathrm{x}}$ Active ingredients in Roundup PowerMax, Valor XLT, Pursuit, Select, and Firstrate are glyphosate, flumioxazin, imazethapyr, clethodium, and cloransulam methyl, respectively. Herbicide Flexstar has both glyphosate and fomesafen and Pursuit Plus has both pendamethalin and imazethapr. COC $=$ crop oil concentrate applied at $1 \%(\mathrm{vol} / \mathrm{vol})$ and AMS $=$ ammonium sulfate applied at $1.25 \%(\mathrm{vol} / \mathrm{vol})$.

${ }^{\mathrm{y}}$ Growth stages of soybean: V3 $=$ third trifoliate and V4 $=$ fourth trifoliate.

${ }^{\mathrm{z}}$ Preemergence rate varied by state: preemergence application in Illinois was Valor XLT ( $0.11 \mathrm{~kg}$ a.i./ha), in Indiana was Valor XLT ( $0.11 \mathrm{~kg}$ a.i./ha), in Iowa was Pursuit Plus (1.01 kg a.i./ha), and in Wisconsin was Valor (0.08 kg a.i./ha) + FirstRate (0.03 kg a.i./ha). 
(FDI) and severity (FDS) was assessed using a 1-to-9 scale as follows: $1=1$ to $10 \%$ of leaf surface chlorotic, or 1 to $5 \%$ necrotic; 2 $=10$ to $20 \%$ of leaf surface chlorotic, or 6 to $10 \%$ necrotic; $3=20$ to $40 \%$ of leaf surface chlorotic, or 11 to $20 \%$ necrotic; $4=40$ to $60 \%$ of leaf surface chlorotic, or 21 to $40 \%$ necrotic; $5=$ greater than $60 \%$ of leaf surface chlorotic, or greater than $40 \%$ necrotic; 6 $=$ premature leaf drop up to one-third defoliation; $7=$ premature leaf drop up to two-thirds defoliation; $8=$ premature leaf drop greater than two-thirds defoliation; and $9=$ premature death. For each disease measure, a foliar disease index (FDX) was calculated using the formula FDX $=$ FDI $\times$ FDS/9 (44).

Twenty of the youngest fully expanded trifoliate leaves with petioles were randomly collected from each plot at 10 locationyears after the last POST herbicide application to determine the nutrient content in plant tissue. Tissue samples were dried, ground following the protocol described by Henry et al. (31), and sent to various laboratories for nutrient analysis. Iowa and Illinois samples were analyzed at the Iowa State University Soil and Plant Analysis Laboratory in Ames; Indiana and Michigan samples at the A\&L

Table 4. Mean foliar disease index (FDX) of sudden death syndrome (SDS) and soybean yield in 14 field experiments conducted in five states in the United States and one province in Canada during the years 2011,2012, and 2013

\begin{tabular}{lcc}
\hline & \multicolumn{2}{c}{ Mean $^{\mathbf{y}}$} \\
\cline { 2 - 3 } Year, location & FDX $^{\mathbf{z}}$ & Yield (kg/ha) \\
\hline 2011 & & \\
Iowa & $0.0 \mathrm{e}$ & $3,016 \mathrm{ef}$ \\
Illinois & $3.9 \mathrm{de}$ & $4,203 \mathrm{ab}$ \\
Indiana & $0.0 \mathrm{e}$ & $2,649 \mathrm{f}$ \\
Wisconsin & $0.0 \mathrm{e}$ & $4,026 \mathrm{bc}$ \\
2012 & & \\
Iowa & $0.0 \mathrm{e}$ & $3,665 \mathrm{~cd}$ \\
Illinois & $6.6 \mathrm{~cd}$ & $4,010 \mathrm{bc}$ \\
Michigan & $64.8 \mathrm{a}$ & $865 \mathrm{~h}$ \\
Ontario, Canada & $4.0 \mathrm{de}$ & $3,289 \mathrm{de}$ \\
2013 & & \\
Iowa & $22.7 \mathrm{~b}$ & $2,065 \mathrm{~g}$ \\
Illinois & $20.6 \mathrm{~b}$ & $3,206 \mathrm{de}$ \\
Indiana & $0.0 \mathrm{~d}$ & $3,854 \mathrm{bc}$ \\
Michigan & $15.4 \mathrm{bc}$ & $3,095 \mathrm{ef}$ \\
Ontario, Canada & $2.1 \mathrm{de}$ & $3,068 \mathrm{ef}$ \\
Wisconsin & $9.3 \mathrm{~cd}$ & $4,612 \mathrm{a}$ \\
$P>$ F & $<0.01$ & $<0.01$ \\
\hline
\end{tabular}

y Means were compared using Fisher's least significant difference. Means within a column followed by the same letter do not differ significantly at $P=0.05$.

${ }^{\mathrm{z}}$ FDX of SDS was calculated using the formula FDX $=$ FDI $\times$ FDS/9. Disease incidence (FDI) was estimated as percentage of symptomatic plants per plot, and foliar SDS severity (FDS) was scored on a 1-to-9 scale based on percentage of chlorotic and necrotic leaf area, and defoliation.
Great Lakes Laboratories in Fort Wayne, IN; Ontario samples at the A\& L Canada Laboratories Inc. in London, ON; and Wisconsin samples at the University of Wisconsin Soil and Plant Analysis Lab in Madison.

Leaf tissues were analyzed for manganese (Mn), phosphorous $(\mathrm{P})$, potassium $(\mathrm{K})$, sulfur $(\mathrm{S})$, and zinc $(\mathrm{Zn})$ content in all 10 location-years where leaf samples were collected; and, in addition, iron (Fe) was analyzed in Indiana and Wisconsin in 2011 and Indiana, Michigan, and Ontario in 2013.

The center two rows of each plot were mechanically harvested after soybean plants reached physiological maturity, which fell between the last week of September and the first week of October. Grain yield and moisture were recorded, and grain yield was normalized at $13 \%$ moisture.

Analysis of variance (ANOVA) was performed using the statistical procedure PROC MIXED in SAS 9.3 (SAS Institute Inc., Cary, NC). Data from experiments were analyzed in two ways: (i) pooled across locations and (ii) separately. Combined ANOVA was performed by pooling data together from all experiments. Individual years and each of the 14 environments were also analyzed independently to get additional information on the effect of herbicide. Herbicide treatment and location were used as fixed effects and replication within location was used as a random effect for combined analysis. The replication within location was used as an error term to test the effect of location as well. For separate analysis of each experiment, herbicide treatment was used as a fixed effect and replication was used as a random effect. Means were compared using Fisher's least significant difference at $P=0.05$. In addition to the ANOVA, orthogonal contrasts were also used to compare the performance between the groups of treatments (glyphosate and nonglyphosate as well as the PRE and POST glyphosate applications). Field experiments in some of the locations had zero or low disease pressure. Orthogonal contrast was performed by pooling data together only from the locations where FDX was 5 or more. Specifically, data were pooled from six locations (i.e., Illinois, and Michigan in 2012 and Iowa, Illinois, Michigan, and Wisconsin in 2013) for orthogonal contrast. Pearson correlation coefficients were estimated using the PROC CORR in SAS 9.3 to determine the association of SDS with yield.

\section{Results}

Glyphosate and SDS. ANOVA combined over location-years revealed that the disease severity was significantly different across the 14 location-years $(P<0.01)$. The FDX ranged between 0 (no disease) and 65 (Table 4). The highest disease score was observed in Michigan during 2012, while 8 of 14 experiments had zero or $<5$ FDX (Table 4). Irrigated field experiments in Michigan and Illinois also recorded the highest FDX. In addition to difference in soil moisture across the location-years, most of the experiments were tilled before planting while some were planted into no-till fields (Table 1); however, there was no apparent effect associated with

Table 5. Mean foliar disease index (FDX) in six different herbicide treatment combinations applied to examine the effect of glyphosate on sudden death syndrome (SDS) of glyphosate-resistant soybean in field experiments carried out in five states in the United States and one province in Canada during the years 2011, 2012, and 2013

\begin{tabular}{|c|c|c|c|c|c|c|c|c|c|c|c|c|c|c|c|}
\hline \multirow[b]{3}{*}{ Treatment $^{\mathrm{z}}$} & \multicolumn{15}{|c|}{ FDX $^{y}$} \\
\hline & \multicolumn{4}{|c|}{2011} & \multicolumn{4}{|c|}{2012} & \multicolumn{6}{|c|}{2013} & \multirow[b]{2}{*}{ Mean } \\
\hline & IA & IL & IN & $\mathbf{W I}$ & IA & IL & MI & ON & IA & IL & IN & MI & ON & $\overline{\text { WI }}$ & \\
\hline Roundup at V3 & 0.0 & 2.9 & 0.0 & 0.0 & 0.0 & 8.9 & 69.4 & 3.6 & 33.5 & 23.1 & 0.0 & 19.6 & 1.3 & 13.1 & 12.5 \\
\hline Roundup at planting then V3 & 0.0 & 3.9 & 0.0 & 0.0 & 0.0 & 7.5 & 62.5 & 3.6 & 19.7 & 22.6 & 0.0 & 13.5 & 2.8 & 9.4 & 10.4 \\
\hline Roundup at V3 then 3 weeks later & 0.0 & 6.2 & 0.0 & 0.0 & 0.0 & 3.2 & 69.4 & 3.1 & 17.0 & 19.0 & 0.0 & 11.1 & 1.9 & 16.4 & 10.5 \\
\hline PRE then Roundup at V3 & 0.0 & 2.5 & 0.0 & 0.0 & 0.0 & 3.6 & 55.6 & 5.6 & 29.4 & 21.9 & 0.0 & 12.3 & 2.2 & 4.9 & 9.9 \\
\hline PRE then Flexstar + Select at V3 & 0.0 & 2.7 & 0.0 & 0.0 & 0.0 & 4.9 & 68.1 & 3.9 & 13.9 & 19.0 & 0.0 & 13.6 & 0.7 & 1.5 & 9.2 \\
\hline PRE then Pursuit at V3 & 0.0 & 4.8 & 0.0 & 0.0 & 0.0 & 11.4 & 63.9 & 4.4 & 22.5 & 18.3 & 0.0 & 22.5 & 3.6 & 10.3 & 11.5 \\
\hline$P>\mathrm{F}$ & 0.77 & 0.82 & NT & NT & NT & 0.26 & 0.53 & 0.9 & 0.44 & 0.55 & NT & 0.46 & 0.33 & 0.50 & 0.12 \\
\hline
\end{tabular}

${ }^{y}$ FDX of SDS was calculated using the formula FDX $=$ FDI $\times$ FDS/9. Disease incidence (FDI) was estimated as percentage of symptomatic plants per plot and foliar SDS severity (FDS) was scored on a 1-to-9 scale based on percentage of the necrotic leaf area. IA = Iowa, IL = Illinois, IN = Indiana, WI = Wisconsin, $\mathrm{MI}=$ Michigan, and ON = Ontario, Canada. NT = not tested.

${ }^{z}$ PRE $=$ before soybean emergence, V3 = third trifoliate stage of soybean. Details of each treatment explained in Table 3. 
tillage in this study. Analysis demonstrated that herbicide treatments and herbicide-experiment interactions did not significantly affect disease severity (Table 5). Among the six treatments, averaged over all locations, FDX ranged from 9 to 13 (Table 5). Plots that received only a single POST glyphosate treatment had an $\mathrm{FDX}=13$, which was not statistically different from other treatments (Table 5).

In 2011, low disease levels were observed in all field experiments (Table 4). Data analysis combined over locations in 2011 indicated that location did not have a significant effect on FDX $(P$ $=0.15$ ), probably due to low disease levels. Of these four experimental locations, Indiana and Wisconsin observed no foliar disease symptoms, and other locations also had extremely low levels of disease ( $<5$ FDX; Table 4). Individual analysis for each environment showed that herbicide treatments did not have any effect on disease severity in any of the field experiments in 2011 (Table 5).

Data analysis combining four field experiments conducted in 2012 exhibited variable disease indices across locations $(P<$ 0.001). The average FDX for 2012 was 0 to 65 (Table 4). FDX was highest in the Michigan experiment $(\mathrm{FDX}=65)$ compared with other locations in 2012 (Table 4). No visible symptoms were evident in Iowa (Table 4). Field experiments in Ontario and Illinois also had low levels of SDS (4 and 7 FDX, respectively). Herbicide $(P=0.53)$ and the herbicide-location interaction $(P=0.50)$ were not statistically significant in 2012. Individual analysis for each location in 2012 showed that none of the experiments had significant herbicide effect (Table 5).

In 2013, combined ANOVA for FDX showed that disease index was different $(P<0.01)$ across the six field experiments. Mean FDX ranged from 0 to 23. The highest disease was observed in Iowa $($ FDX $=23)$, followed by Illinois $($ FDX $=21)$. No visible foliar symptoms were observed in Indiana. FDX was 15, 2, and 9 in Michigan, Ontario, and Wisconsin, respectively. No statistically significant effects on FDX as a result of herbicide treatment $(P=$
$0.15)$ or herbicide-location interactions $(P=0.68)$ were observed. Individual analysis also showed that herbicide treatments were not statistically different in any of the field experiments (Table 5).

ANOVA was performed in two ways: pooled across locations as well as separate for each location. All analyses indicated that FDX was not different across herbicide treatments (Table 5). In addition to the ANOVA, orthogonal contrasts to compare the performance between the groups of treatments (glyphosate and nonglyphosate as well as the PRE and POST glyphosate applications) also showed SDS severity did not differ between treatments that received glyphosate and those that did not (Table 6). Similarly, SDS severity was not different between treatments of only POST glyphosate applications and treatments with both PRE and POST applications (Table 6). Herbicide treatments and herbicide-experiment interactions did not have an effect on disease severity (Table 5).

Glyphosate and yield. Soybean grain yield was different among the 14 location-years $(P<0.01)$. Pooled analysis showed a significant treatment-location interaction $(P<0.01)$; therefore, yield response for treatments was also analyzed separately for each location. Significant effects on yield due to herbicide treatments were observed only in some location-years (Table 7). In all, 3 of the 14 locations (Wisconsin during 2011 and Iowa and Ontario during 2013) had soybean yield affected by herbicide treatment, and yield was higher in glyphosate-applied plots compared with other herbicide-treated plots $(P<0.05$; Table 7). Among the six treatments evaluated, treatments of glyphosate application at planting and then 3 weeks later resulted in the highest yield in Wisconsin during 2011 $(4,257 \mathrm{~kg} / \mathrm{ha})$. Treatments of a double rate $(3.25 \mathrm{~kg} / \mathrm{ha})$ of glyphosate application at V3 and glyphosate application at V3 and 3 weeks later produced the highest yield in Ontario $(3,257 \mathrm{~kg} / \mathrm{ha})$ and Iowa $(2,630$ $\mathrm{kg} / \mathrm{ha}$ ), respectively, during 2013.

Correlation analysis revealed that yield had a negative correlation with FDX $(P<0.01, r=-0.67)$. Fields with high FDX had lower grain yield and vice versa. For instance, the experiments

Table 6. Orthogonal contrast among treatment groups applied to glyphosate-resistant soybean in field experiments carried out in five states (Iowa, Illinois, Indiana, Michigan, and Wisconsin) in the United States and one province in Canada (Ontario) during 2012 and 2013 growing seasons ${ }^{\mathrm{x}}$

\begin{tabular}{lcc}
\hline & & $P>\mathbf{F}$ \\
Year, parameters & FDX $^{\mathbf{y}}$ & Yield \\
\hline 2012 & & \\
Glyphosate versus nonglyphosate & 0.47 & 0.94 \\
Glyphosate PRE+POST versus POST only & 0.99 & \\
2013 & & $<0.01$ \\
Glyphosate versus nonglyphosate & 0.25 & 0.55 \\
Glyphosate PRE+POST versus POST only & 0.50 & \\
\hline
\end{tabular}

${ }^{x}$ Contrasts were performed by pooling field experiments having $\geq 5 \%$ foliar disease index (FDX) only; none of the experiments had $\geq 5$ FDX in 2011.

${ }^{y}$ Foliar disease index (FDI) of sudden death syndrome (SDS) was calculated using the formula FDX $=$ FDI $\times$ FDS/9. Disease incidence (FDI) was estimated as percentage of symptomatic plants per plot and foliar SDS severity (FDS) was scored on a 1-to-9 scale based on percentage of the chlorotic and necrotic leaf area and defoliation.

${ }^{\mathrm{z}}$ Contrast was performed within the four glyphosate treatments between glyphosate pre- and postemergence versus plots which had postemergence only.

Table 7. Mean soybean yield for different herbicide treatments applied to examine the effect of glyphosate on sudden death syndrome of glyphosate-resistant soybean in a field study carried out in five states of the United States and one province in Canada during the years 2011, 2012, and 2013

\begin{tabular}{|c|c|c|c|c|c|c|c|c|c|c|c|c|c|c|c|}
\hline \multirow[b]{3}{*}{ Treatment $^{\mathrm{z}}$} & \multicolumn{15}{|c|}{ 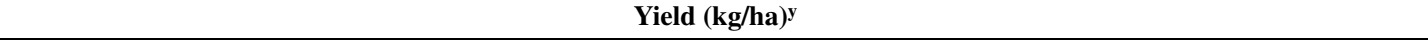 } \\
\hline & \multicolumn{4}{|c|}{2011} & \multicolumn{4}{|c|}{2012} & \multicolumn{6}{|c|}{2013} & \multirow[b]{2}{*}{ Mean } \\
\hline & IA & IL & IN & WI & IA & IL & MI & ON & IA & IL & IN & MI & ON & WI & \\
\hline Roundup at V3 & 2,935 & 4,183 & 2,485 & $4,009 \mathrm{ab}$ & 3,456 & 4,171 & 929 & 3,176 & $2,165 \mathrm{ab}$ & 3,265 & 3,959 & 3,000 & $3,257 \mathrm{a}$ & 4,510 & 3,249 \\
\hline Roundup at planting then $\mathrm{V} 3$ & 2,909 & 4,144 & 2,530 & 4,257 a & 3,722 & 4,252 & 729 & 3,545 & $2,603 \mathrm{a}$ & 3,191 & 3,848 & 3,060 & $3,242 \mathrm{a}$ & 4,700 & 3,338 \\
\hline \multicolumn{16}{|l|}{ Roundup at V3 then } \\
\hline 3 weeks later & 2,987 & 4,075 & 2,632 & $3,866 \mathrm{~b}$ & 3,627 & 3,845 & 690 & 3,277 & $2,632 \mathrm{a}$ & 3,223 & 3,967 & 3,300 & $3,227 \mathrm{a}$ & 4,720 & 3,291 \\
\hline PRE then Roundup at V3 & 3,063 & 4,132 & 2,856 & $4,062 \mathrm{a}$ & 3,423 & 3,613 & 1,254 & 3,090 & $1,913 \mathrm{ab}$ & 3,241 & 3,778 & 3,390 & $2,992 \mathrm{ab}$ & 4,590 & 3,243 \\
\hline \multicolumn{16}{|l|}{ PRE then Flexstar + } \\
\hline Select at V3 & 3,220 & 4,212 & 2,597 & $4,111 \mathrm{a}$ & 3,790 & 3,976 & 761 & 3,385 & $1,322 \mathrm{~b}$ & 3,146 & 3,856 & 3,040 & $2,816 \mathrm{~b}$ & 4,550 & 3,198 \\
\hline PRE then Pursuit at V3 & 2,984 & 4,470 & 2,804 & $3,851 \mathrm{~b}$ & 3,971 & 4,205 & 830 & 3,261 & $1,754 \mathrm{~b}$ & 3,172 & 3,414 & 2,780 & $2,871 \mathrm{~b}$ & 4,610 & 3,234 \\
\hline$P>\mathrm{F}$ & 0.77 & 0.23 & 0.45 & 0.03 & 0.55 & 0.16 & 0.28 & 0.29 & 0.02 & 0.94 & 0.43 & 0.13 & 0.03 & 0.86 & 0.24 \\
\hline
\end{tabular}

y Means were compared using Fisher's least significant difference. Means within a column followed by the same letter do not differ significantly at $P=0.05$. $\mathrm{IA}=$ Iowa, $\mathrm{IL}=$ Illinois, $\mathrm{IN}=$ Indiana, $\mathrm{WI}=$ Wisconsin, $\mathrm{MI}=$ Michigan, and ON = Ontario, Canada.

${ }^{\mathrm{z}} \mathrm{PRE}=$ before soybean emergence, $\mathrm{V} 3=$ third trifoliate stage of soybean. Details of each treatment explained in Table 3. 
with the highest SDS index (FDX $=65)$ had the lowest yield (865 $\mathrm{kg} \mathrm{ha}^{-1}$ ) among experiments (Table 4).

Glyphosate and nutrient accumulation in plant tissue. Tissue sample analysis combined over location-years showed that location-years were highly significant $(P<0.01)$ for $\mathrm{P}, \mathrm{K}, \mathrm{Mn}, \mathrm{Zn}$, and $\mathrm{S}$. However, the treatment and treatment-location-year interaction were not significant. Despite literature emphasizing glyphosatemanganese interactions $(19,29)$, this set of experiments did not show treatment effects at any location-year (Table 8). Tissue sample analysis did show significant treatment differences for 7 of 55 nutrient-location-year combinations (Table 9). Results varied across location-year and did not show a clear trend among treatment effects. For instance, treatments receiving PRE applications of nonglyphosate herbicides had significantly lower $\mathrm{P}$ content than treatments containing glyphosate in both Michigan and Ontario in 2013. However, in Indiana in 2011 and Iowa in 2013, treatments that did not include glyphosate resulted in significantly higher $\mathrm{P}$ content in tissue samples (Table 9).

\section{Discussion}

This study revealed that SDS FDX in soybean was not influenced by different herbicide treatments or location-herbicide interactions across diverse locations and environments. Glyphosate treatments did not result in higher foliar SDS levels compared with treatments without glyphosate. This result substantiates the study by Njiti et al. (43), which showed no effect of glyphosate on SDS development. Similar to this result, previous investigations on charcoal rot (caused by Macrophomina phaseolina (Tassi) Goid. and Rhizoctonia root rot (caused by Rhizoctonia solani Kühn) also concluded that glyphosate application had no significant association with disease severity $(11,60)$. The findings of this study do not agree with the studies $(1,33,42,54,55)$ which reported that SDS severity was affected by glyphosate application. Higher levels of
SDS severity in the inoculated plants after herbicide application was reported previously by Sanogo et al. $(54,55)$; however, the reaction was not restricted only to glyphosate herbicide and the GR trait. Previous reports were inconclusive about the effect of glyphosate on soybean diseases $(7,39,54)$. Sanogo et al. (54) reported that glyphosate reduced fungal growth and sporulation in culture but, surprisingly, increased SDS severity compared with no herbicide control in greenhouse and growth chamber observations. Inconsistent effects of glyphosate in field and greenhouse studies have also been reported for Rhizoctonia root rot of soybean (7). The inconsistencies between laboratory versus greenhouse or controlled environment versus field conditions might be related to different concentrations of inoculum and herbicides or different evaluation stages in the two environments. In addition, the effect of glyphosate may be minimal; although noticed under controlled conditions, it might not have been observed in this study because of the interaction with environmental, cultivar, and soil factors.

Our results also showed that SDS severity varied across locations and years. The difference in disease severity across different locations might be from differences in weather, soybean cultivars, and soil factors. FDX was very low or not evident in some field experiments that presumably had environments not conducive for plant infection by $F$. virguliforme. The highest FDX was recorded in Michigan, where experimental plots were irrigated in both years. This result indicates that high soil moisture favors SDS development, which was in support to the previous reports $(15,35,38$, 43,48,56).

Our results confirm that both SDS and herbicide treatment affected yield. Yield was negatively associated with increasing severity of SDS, which is in agreement with previous reports $(44,52,59)$. In the present study, yield was always higher in treatments where glyphosate was applied, compared with nonglyphosate controls in locations, where treatment effect was significant. The yield differ-

Table 8. Tissue analysis for manganese accumulation in leaf samples collected from field experiments carried out in five states in the United States and one province in Canada during 2011 to 2013 growing seasons

\begin{tabular}{|c|c|c|c|c|c|c|c|c|c|c|}
\hline \multirow[b]{3}{*}{ Treatment $^{\mathrm{z}}$} & \multicolumn{10}{|c|}{ Manganese content $(\mu \mathrm{g} / \mathrm{g})^{\mathrm{y}}$} \\
\hline & \multicolumn{4}{|c|}{2011} & \multirow{2}{*}{$\begin{array}{c}2012 \\
\text { IA }\end{array}$} & \multicolumn{5}{|c|}{2013} \\
\hline & $\mathbf{I A}$ & IL & IN & WI & & IA & IL & IN & MI & $\mathbf{O N}$ \\
\hline Roundup at V3 & 56.5 & 52.8 & 63.0 & 48.8 & 36.8 & 27.0 & 50.5 & 62.5 & 87.2 & 25.8 \\
\hline Roundup at Planting then V3 & 56.5 & 51.0 & 67.0 & 45.5 & 36.0 & 29.0 & 48.3 & 63.3 & 81.9 & 28.3 \\
\hline Roundup at V3 then 3 weeks later & 58.0 & 52.3 & 71.5 & 49.1 & 38.0 & 29.0 & 42.0 & 63.8 & 85.2 & 26.8 \\
\hline PRE then Roundup at V3 & 56.5 & 47.3 & 66.0 & 48.1 & 35.3 & 31.0 & 49.8 & 64.8 & 86.4 & 23.0 \\
\hline PRE then Flexstar + Select at V3 & 59.3 & 51.0 & 69.0 & 46.3 & 36.5 & 31.0 & 49.8 & 66.8 & 90.3 & 22.8 \\
\hline PRE then Pursuit at V3 & 53.3 & 50.0 & 68.0 & 44.9 & 34.8 & 31.0 & 58.5 & 62.8 & 84.4 & 22.8 \\
\hline$P>\mathrm{F}$ & 0.41 & 0.27 & 0.83 & 0.72 & 0.88 & 0.47 & 0.63 & 0.89 & 0.43 & 0.36 \\
\hline
\end{tabular}

y $\mathrm{IA}=$ Iowa, IL = Illinois, IN = Indiana, WI = Wisconsin, MI = Michigan, and ON = Ontario, Canada.

${ }^{\mathrm{z}} \mathrm{PRE}=$ before soybean emergence, $\mathrm{V} 3 \mathrm{=}$ third trifoliate stage of soybean. Details of each treatment explained in Table 3.

Table 9. Tissue analysis results for locations and nutrients with significant effect of herbicide treatments over 55 nutrient-location-years

\begin{tabular}{|c|c|c|c|c|c|c|c|}
\hline \multirow[b]{4}{*}{ Treatment $^{\mathrm{z}}$} & \multicolumn{7}{|c|}{ Mean nutrient content in leaf tissue $(\mu \mathrm{g} / \mathrm{g})^{\mathrm{y}}$} \\
\hline & \multicolumn{2}{|c|}{2011} & \multicolumn{5}{|c|}{2013} \\
\hline & IN & WI & IA & MI & MI & ON & ON \\
\hline & $\mathbf{P}$ & $\mathbf{F e}$ & $\mathbf{P}$ & $\mathbf{F e}$ & $\mathbf{P}$ & $\mathbf{P}$ & $\mathbf{Z n}$ \\
\hline Roundup at V3 & $5,100.0 \mathrm{a}$ & $76.9 \mathrm{~b}$ & $1,791.0 \mathrm{~b}$ & $144.6 \mathrm{~b}$ & $4,425.0 \mathrm{a}$ & $4,350.0 \mathrm{ab}$ & $52.5 \mathrm{ab}$ \\
\hline Roundup at Planting then V3 & $4,900.0 \mathrm{a}$ & $86.1 \mathrm{ab}$ & $1,960.0 \mathrm{ab}$ & $145.7 \mathrm{~b}$ & $4,077.5 \mathrm{ab}$ & $4,650.0 \mathrm{a}$ & $57.0 \mathrm{a}$ \\
\hline Roundup at V3 then 3 weeks later & $4,300.0 \mathrm{~b}$ & $114.7 \mathrm{ab}$ & $1,835.0 \mathrm{~b}$ & $138.7 \mathrm{~b}$ & $4,172.5 \mathrm{ab}$ & $4,725.0 \mathrm{a}$ & $56.5 \mathrm{a}$ \\
\hline PRE then Roundup at V3 & $5,100.0 \mathrm{a}$ & $85.0 \mathrm{ab}$ & $1,885.0 \mathrm{~b}$ & $184.8 \mathrm{a}$ & $3,792.5 \mathrm{bc}$ & $4,125.0 \mathrm{c}$ & $45.8 \mathrm{~b}$ \\
\hline PRE then Flexstar + Select at V3 & $4,950.0 \mathrm{a}$ & $130.5 \mathrm{a}$ & $2,165.0 \mathrm{a}$ & $164.1 \mathrm{ab}$ & $3,792.5 \mathrm{bc}$ & $3,700.0 \mathrm{c}$ & $43.8 \mathrm{~b}$ \\
\hline PRE then Pursuit at V3 & $4,750.0 \mathrm{a}$ & $85.4 \mathrm{ab}$ & $2,136.0 \mathrm{a}$ & $188.2 \mathrm{a}$ & $3,730.0 \mathrm{c}$ & $3,700.0 \mathrm{c}$ & $46.3 \mathrm{~b}$ \\
\hline$P>\mathrm{F}$ & 0.04 & 0.03 & 0.02 & $<0.01$ & 0.01 & $<0.01$ & 0.02 \\
\hline
\end{tabular}

${ }^{y}$ Leaf tissues were analyzed for phosphorous $(\mathrm{P})$, potassium $(\mathrm{K})$, manganese $(\mathrm{Mn})$, zinc $(\mathrm{Zn})$, and sulfur (S) content in all 10 location-years where leaf sample was taken; and iron (Fe) in addition was analyzed in Wisconsin and Indiana during 2011 and in Ontario, Michigan, and Indiana in 2013. All other nutrients tested were not statistically significant in any of the site-years. IN = Indiana, WI = Wisconsin, IA = Iowa, MI = Michigan, and ON = Ontario, Canada. Means were compared using Fisher's least significant difference. Means within a column followed by the same letter do not differ significantly at $P=0.05$.

${ }^{\mathrm{z}} \mathrm{PRE}=$ before soybean emergence, $\mathrm{V} 3=$ third trifoliate stage of soybean. Details of each treatment explained in Table 3. 
ence in those experiments was most likely due to higher weed infestation in nonglyphosate treatments, although weeds were not the focus of this study and detailed data regarding weed control are not shown in this report. Excellent weed control for a broad spectrum of weeds from glyphosate applications is well documented in the literature; therefore, this is not surprising. Additionally, Njiti et al. (43) in a field study reported higher grain yield in some SDS-susceptible cultivars sprayed with glyphosate.

Our research showed that glyphosate was not interacting with manganese as measured by tissue analysis across all locations and years. Nutrient tissue analysis differences among treatments across the locations could have been associated with soil nutrient levels, environmental conditions, or soybean genetics. Overall, this research was inconclusive in determining the effect of glyphosate on nutrient accumulation in plant tissue; however, experimental fields were selected based on history of SDS, and soil from each site was not analyzed to determine whether underlying nutrient deficiencies were present that could influence results. Based on yield data and the fact that no nutrient deficiencies were visually apparent at any location, glyphosate did not appear to cause any detectable detrimental effects to plant nutrient levels required for normal growth and development.

Although this study provides new field-based results on the impact of glyphosate on SDS, future studies should be conducted to determine the impact of glyphosate under high disease pressure and extremely favorable (inoculated and irrigated) environments for disease development. Nonetheless, although recent claims have suggested that glyphosate increases SDS severity, results from our multiyear and location trials did not corroborate these observations. These results indicate that soybean farmers do not need to change herbicide programs or apply additional supplementary micronutrients to soybean specifically for SDS management. Instead, farmers are encouraged to prevent loss by adopting other SDS management strategies such as selecting less susceptible varieties, implementing cultural practices to reduce conditions favorable for disease development, and avoiding fields with a history of severe SDS.

\section{Acknowledgments}

The study was partially supported by soybean check-off programs through the North Central Soybean Research Program as well as The Grain Farmers of Ontario, who obtained funding from the Ontario Farm Innovation Program (OFIP), which is administered by the Agricultural Adaptation Council. We thank farmer cooperators C. and A. Druskovich, Decatur, MI; and K. Ames, S. Thomas, and J. Weems from the University of Illinois, Urbana; N. Anderson, G. Buechley, W. Johnson, M. Lanera, D. Nootens, J. Ravellette, D. Teska, J. Young, and Z. Sexton from Purdue University, West Lafayette, IN; S. Wiggs from Iowa State University, Ames; J. Boyse, A. Byrne, J. Jacobs, R. Laurenz, A. Rojas, J. Wang, and B. MacKellar from Michigan State University, East Lansing; S. Conley and J. Gaska from University of Wisconsin-Madison; and G. Kotulak and C. Van Herk from Ontario Ministry of Agriculture and Food, Ridgetown, $\mathrm{ON}$ for their technical assistance in conducting this trial.

\section{Literature Cited}

1. Anderson, J. A., and Kolmer, J. A. 2005. Rust control in glyphosate tolerant wheat following application of the herbicide glyphosate. Plant Dis. 89:1136-1142.

2. Anderson, T., and Tenuta, A. 1998. First report of Fusarium solani f. sp. glycines causing sudden death syndrome of soybean in Canada. Plant Dis. 82:448-448.

3. Aoki, T., O'Donnell, K., Homma, Y., and Lattanzi, A. R. 2003. Suddendeath syndrome of soybean is caused by two morphologically and phylogenetically distinct species within the Fusarium solani species complex-F. virguliforme in North America and F. tucumaniae in South America. Mycologia 95:660-684.

4. Aoki, T., O'Donnell, K., and Scandiani, M. M. 2005. Sudden death syndrome of soybean in South America is caused by four species of Fusarium: Fusarium brasiliense sp. nov., F. cuneirostrum sp. nov., F. tucumaniae, and F. virguliforme. Mycoscience 46:162-183.

5. Aoki, T., Scandiani, M., and O’Donnell, K. 2012. Phenotypic, molecular phylogenetic, and pathogenetic characterization of Fusarium crassistipitatum sp. nov., a novel soybean sudden death syndrome pathogen from Argentina and Brazil. Mycoscience 53:167-186.

6. Bellaloui, N., Reddy, K. N., Zablotowicz, R. M., Abbas, H. K., and Abel, C. A. 2009. Effects of glyphosate application on seed iron and root ferric (III) reductase in soybean cultivars. J. Agric. Food Chem. 57:9569-9574.

7. Bradley, C. A., Hartman, G. L., Wax, L. M., and Pedersen, W. L. 2002. In- fluence of herbicides on Rhizoctonia root and hypocotyl rot of soybean. Crop Prot. 21:679-687.

8. Brar, H. K., and Bhattacharyya, M. K. 2012. Expression of a single-chain variable-fragment antibody against a Fusarium virguliforme toxin peptide enhances tolerance to sudden death syndrome in transgenic soybean plants. Mol. Plant-Microbe Interact. 25:817-824.

9. Cakmak, I., Yazici, A., Tutus, Y., and Ozturk, L. 2009. Glyphosate reduced seed and leaf concentrations of calcium, manganese, magnesium, and iron in non-glyphosate resistant soybean. Eur. J. Agron. 31:114-119.

10. Camberato, J., Wise, K., and Johnson, B. 2010. Glyphosate-manganese interactions and impacts on crop production: The controversy. Purdue University Extension Weed Science. Online publication. http://www.btny. purdue.edu/weedscience/2010/GlyphosateMn.pdf

11. Canaday, C., Helsel, D., and Wyllie, T. 1986. Effects of herbicide-induced stress on root colonization of soybeans by Macrophomina phaseolina. Plant Dis. 70:863-866.

12. Cho, J., Rupe, J., Cummings, M., and Gbur, E., Jr. 2001. Isolation and identification of Fusarium solani f. sp. glycines from soil on modified Nash and Snyder's medium. Plant Dis. 85:256-260.

13. Coulter, J. A., and Emerson, D. N. 2007. Planting date and glyphosate timing on soybean. Weed Technol. 21:359-366.

14. Dalley, C. D., Kells, J. J., and Renner, K. A. 2004. Effect of glyphosate application timing and row spacing on corn (Zea mays) and soybean (Glycine max) yields. Weed Technol. 18:165-176

15. de Farias Neto, A. L., Hartman, G. L., Pedersen, W. L., Li, S., Bollero, G A., and Diers, B. W. 2006. Irrigation and inoculation treatments that increase the severity of soybean sudden death syndrome in the field. Crop Sci. 46:2547-2554.

16. de Farias Neto, A. L., Hashmi, R., Schmidt, M., Carlson, S. R., Hartman, G. L., Li, S., Nelson, R. L., and Diers, B. W. 2007. Mapping and confirmation of a new sudden death syndrome resistance QTL on linkage group D2 from the soybean genotypes PI 567374 and 'Ripley'. Mol. Breed. 20:53-62.

17. Dodds, D. M., Hickman, M. V., and Huber, D. M. 2001. Comparison of micronutrient uptake by glyphosate resistant and non-glyphosate resistant soybeans. Proc. North Central Weed Sci. 56:96.

18. Dodds, D. M., Huber, D. M., and Hickman, M. V. 2002. Micronutrient levels in normal and glyphosate-resistant soybean. Proc. North Central Weed Sci. 57:107.

19. Duke, S. O., Lydon, J., Koskinen, W. C., Moorman, T. B., Chaney, R. L., and Hammerschmidt, R. 2012. Glyphosate effects on plant mineral nutrition, crop rhizosphere microbiota, and plant disease in glyphosate-resistant crops. J. Agric. Food Chem. 60:10375-10397.

20. Ebelhar, S. A., Varsa, E. C., and Hart, C. D. 2006. Soil pH and manganese effects on yield of Roundup Ready soybeans. Pages 54-65 in: Ill. Fertil. Conf. Proc., Peoria, IL.

21. Fehr, W. R., Caviness, C. E., Burmood, D. T., and Pennington, J. S. 1971. Stage of development descriptions for soybeans, Glycine max (L.) Merrill. Crop Sci. 11:929-931.

22. Feng, P. C. C., Baley, G. J., Clinton, W. P., Bunkers, G. J., Alibhai, M. F., Paulitz, T. C., and Kidwell, K. K. 2005. Glyphosate inhibits rust diseases in glyphosate-resistant wheat and soybean. Proc. Natl. Acad. Sci. USA 102:17290-17295.

23. Fernandez, M. R., Zentner, R. P., Basnyat, P., Gehl, D., Selles, F., and Huber, D. 2009. Glyphosate associations with cereal diseases caused by Fusarium spp. in the Canadian prairies. Eur. J. Agron. 31:133-143.

24. Gibson, P. T., Shenaut, M. A., Njiti, V. J., Suttner, R. J., and Myers, O., Jr. 1994. Soybean varietal response to sudden death syndrome. Am. Seed Trade Assoc. 24th Soybean Res. Conf. 24:20-40.

25. Gongora-Canul, C., and Leandro, L. 2011. Effect of soil temperature and plant age at time of inoculation on progress of root rot and foliar symptoms of soybean sudden death syndrome. Plant Dis. 95:436-440.

26. Graham, M. J., Nickell, C. D., and Hoeft, R. G. 1995. Inheritance of tolerance to manganese deficiency in soybean. Crop Sci. 35:1007-1010.

27. Harikrishnan, R., and Yang, X. B. 2002. Effects of herbicides on root rot and damping-off caused by Rhizoctonia solani in glyphosate-tolerant soybean. Plant Dis. 86:1369-1373.

28. Hartman, G., Huang, Y., Nelson, R., and Noel, G. 1997. Germplasm evaluation of Glycine max for resistance to Fusarium solani, the causal organism of sudden death syndrome. Plant Dis. 81:515-518.

29. Hartman, G. L., Gardner, M. E., Hymowitz, T., and Naidoo, G. C. 2000. Evaluation of perennial Glycine species for resistance to soybean fungal pathogens that cause Sclerotinia stem rot and sudden death syndrome. Crop Sci. 40:545-549.

30. Hartzler, B. 2010. Glyphosate-manganese interactions in roundup ready soybean. Iowa State University Weed Science. Online publication. http://www.weeds.iastate.edu/mgmt/2010/glymn.pdf

31. Henry, R. S., Wise, K. A., and Johnson, W. G. 2011. Glyphosate's effect upon mineral accumulation in soybean. Online publication. Crop Manage. Online publication. doi:10.1094/CM-2011-1024-01-RS

32. Huber, D. M. 2007. What about glyphosate-induced manganese deficiency? Fluid 15:20-22.

33. Johal, G. S., and Huber, D. M. 2009. Glyphosate effects on diseases of plants. Eur. J. Agron. 31:144-152.

34. Kremer, R. J., and Means, N. E. 2009. Glyphosate and glyphosate-resistant 
crop interactions with rhizosphere microorganisms. Eur. J. Agron. 31:153161.

35. Leandro, L. F., Tatalovic, N., and Luckew, A. 2012. Soybean sudden death syndrome-Advances in knowledge and disease management. CAB Rev. 7:1-14.

36. Li, S., Hartman G. L., and Chen, Y. 2009. Evaluation of aggressiveness of Fusarium virguliforme isolates that cause soybean sudden death syndrome. J. Plant Pathol. 91:77-86.

37. Loecker, J. L., Nelson, N. O., Gordon, W. B., Maddux, L. D., Janssen, K. A., and Schapaugh, W. T. 2010. Manganese response in conventional and glyphosate resistant soybean. Agron. J. 102:606-611.

38. Melgar, J., Roy, K. W., and Abney, T. S. 1994. Sudden death syndrome of soybean: Etiology, symptomatology, and effects of irrigation and Heterodera glycines on incidence and severity under field conditions. Can. J. Bot. 72:1647-1653.

39. Mengistu, A., Reddy, K. N., Bellaloui, N., Walker, E. R., and Kelly, H. M. 2013. Effect of glyphosate on Macrophomina phaseolina in vitro and its effect on disease severity of soybean in the field. Crop Prot. 54:23-28.

40. Mueller, D., Hartman, G., Nelson, R., and Pedersen, W. 2002. Evaluation of Glycine max germplasm for resistance to Fusarium solani f. sp. glycines. Plant Dis. 86:741-746.

41. Mueller, D., Nelson, R., Hartman, G., and Pedersen, W. 2003. Response of commercially developed soybean cultivars and the ancestral soybean lines to Fusarium solani f. sp. glycines. Plant Dis. 87:827-831.

42. Navi, S. S., Jing, L., and Yang, X. 2012. Effects of glyphosate application rates on soybean sudden death syndrome. (Abstr.) Phytopathology 102:S4.86.

43. Njiti, V. N., Mayers O., Schroeder D., and Lightfoot D. A. 2003. Roundup ready soybean: Glyphosate effects on Fusarium solani root colonization and sudden death syndrome. Agron. J. 95:1140-1145.

44. Njiti, V. N., Shenaut, M. A., Suttner, R. J., Schmidt, M. E., and Gibson, P. T. 1998. Relationship between soybean sudden death syndrome disease measures and yield components in F6-derived lines. Crop Sci. 38:673-678.

45. Rosolem, C. A., de Andrade, G. J. M., Lisboa, I. P., and Zoca, S. M. 2010. Manganese uptake and redistribution in soybean as affected by glyphosate. Rev. Bras. Ciênc. Solo 34:1915-1922.

46. Roy, K. 1997. Fusarium solani on soybean roots: Nomenclature of the causal agent of sudden death syndrome and identity and relevance of $F$. solani form B. Plant Dis. 81:259-266.

47. Roy, K., Hershman, D., Rupe, J., and Abney, T. 1997. Sudden death syn- drome of soybean. Plant Dis. 81:1100-1111.

48. Roy, K., Lawrence, G., Hodges, H., McLean, K., and Killebrew, J. 1989. Sudden death syndrome of soybean: Fusarium solani as incitant and relation of Heterodera glycines to disease severity. Phytopathology 79:191-197.

49. Rupe, J., Gbur, E., and Marx, D. 1991. Cultivar responses to sudden death syndrome of soybean. Plant Dis. 75:47-50.

50. Rupe, J., and G. Hartman. 1999. Sudden death syndrome. Pages 37-39 in: Compendium of Soybean Diseases. G. L. Hartman, J. B. Sinclair, and J. C. Rupe, eds. American Phytopathological Society, St. Paul, MN.

51. Rupe, J., Robbins, R., and Gbur, E. 1997. Effect of crop rotation on soil population densities of Fusarium solani and Heterodera glycines and on the development of sudden death syndrome of soybean. Crop Prot. 16:575-580.

52. Rupe, J., Sabbe, W., Robbins, R., and Gbur, E. 1993. Soil and plant factors associated with sudden death syndrome of soybean. J. Prod. Agric. 6:218 221.

53. Sammons, D. R., and Tran, M. 2008. Examining yellow flash in roundup ready soybean. Proc. North Central Weed Sci. 63:120.

54. Sanogo, S., Yang, X., and Scherm, H. 2000. Effects of herbicides on Fusarium solani f. sp. glycines and development of sudden death syndrome in glyphosate-tolerant soybean. Phytopathology 90:57-66.

55. Sanogo, S., Yang, X. B., and Lundeen, P. 2001. Field response of glyphosate-tolerant soybean to herbicides and sudden death syndrome. Plant Dis. 85:773-779.

56. Scherm, H., and Yang, X. 1996. Development of sudden death syndrome of soybean in relation to soil temperature and soil water matric potential. Phytopathology 86:642-649.

57. Scherm, H., Yang, X., and Lundeen, P. 1998. Soil variables associated with sudden death syndrome in soybean fields in Iowa. Plant Dis. 82:1152-1157.

58. U.S. Dep. Agric. Adoption of genetically engineered crops in the U.S: Recent trends in GE adoption. USDA Economic Research Service. Online publication. http://www.ers.usda.gov/data-products/adoption-of-geneticallyengineered-crops-in-the-us/recent-trends-in-ge-adoption.aspx\#.U4eWUS_ ant4

59. Wrather, J., and Koenning, S. 2009. Effects of diseases on soybean yields in the United States 1996 to 2007. Online publication. Plant Health Progress doi:10.1094/PHP-2009-0401-01-RS

60. Zhang, R. 2011. Interactions of post emergence herbicides, strobilurin fungicides and Rhizoctonia root rot of soybean. Master's thesis, University of Illinois at Urbana-Champaign. Online publication. https://ideals.illinois edu/bitstream/handle/2142/29445/ZHANG_REN.pdf?sequence=1 